\title{
Enkephalinase: Selective Inhibitors and Partial Characterization
}

\author{
SUE SULLIVAN, HUDA AKIL, ${ }^{*}$ DEBORAH BLACKER AND JACK D. BARCHAS \\ Nancy Pritzker Laboratory of Behavioral Neurochemistry, Department of Psychiatry and Behavioral Sciences \\ Stanford University School of Medicine, Stanford, CA 94305 \\ and \\ *Mental Health Research Institute, University of Michigan, Ann Arbor, MI 48109
}

Received 10 March 1980

\begin{abstract}
SULLIVAN, S., H. AKIL, D. BLACKER AND J. D. BARCHAS. Enkephalinase: Selective inhibitors and partial characterization. PEPTIDES 1(1) 31-35, 1980.-There are at least two types of enzymes in brain, endopeptidases and aminopeptidases, which metabolize enkephalins. Evidence is presented to suggest that enkephalinase, an endopeptidase cleaving at the Gly-Phe bond, is specific for the endogenous enkephalinergic system. Selective inhibitors are described for each enzyme. These are parachloromercuriphenylsulfonic acid and puromycin in the case of aminopeptidases and various enkephalin fragments in the case of enkephalinase. Some characteristics of the two types of enzymes are described. Enkephalinase has many properties in common with the well-characterized brain angiotensin-converting enzyme. These two enzymes, however, behaved differently when tested for chloride dependance, for activity in several buffers and for susceptibility to specific inhibitors.
\end{abstract}

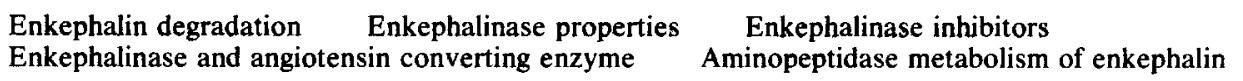

SINCE the isolation from brain of the endogenous opiatelike peptides methionine- and leucine-enkephalin (ME and LE) [14], interest has been focused upon finding their physiological roles. These peptides apparently act as neurotransmitters in brain: they are released in a $\mathrm{CA}^{++}$-dependent fashion by depolarization of striatal slices, are present in synaptosomes $[13,15]$ and are localized in cell bodies and along beaded axons of interneurones $[6,22,29]$. With elucidation of modes of synthesis and inactivation at the synapse, additional requirements for the establishment of these substances as neurotransmitters will be fulfilled. Synthetic mechanisms for these peptides remain unclear. There appear to be at least two modes of inactivation in brain, one via cleavage of the N-terminal Tyr-Gly bond by (an) amino peptidase(s) $[4,12,18,19,20]$ and a second via cleavage of the Gly-Phe bond $[16,24,25]$ by (an) endopeptidase(s). In both cases enzymatic activity is probably comprised of a number of peptidases. Amino peptidases are more soluble enzymes with brain distributions which do not follow that of enkephalin or the opiate receptor $[20,24,25]$. On the other hand, there is an endopeptidase which is membrane bound with a distribution in brain which parallels the opiate receptor $[16,17,24,25]$, suggesting that it is specific for the endogenous enkephalinergic system. The endopeptidase has been termed enkephalinase by some authors. Graves et al. [10] have recently demonstrated in vivo generation of TyrGly-Gly (TGG) upon administration of ${ }^{3} \mathrm{H}$-enkephalin in brain, lending further credence to the idea that this endopeptidase is physiologically significant.
A purified peptidyldipeptidase identical to the angiotension converting enzyme ( $A C E$ ) has been described as being capable of cleaving enkephalin at the Gly-Phe bond [8]. ACE has also been demonstrated to be present in brain $[2,21,30]$. This information engendered speculation on the part of Benuck and Marks [3], Swerts et al. [26], and Snyder [23] that brain enkephalinase activity may be attributable to ACE.

In this paper we describe some work with inhibitors of the endopeptidase (enkephalinase) and amino peptidases, aimed at a preliminary characterization of these enzymes. The pharmacological use of selective inhibitors may later help to elucidate the roles of each mode of deactivation. In addition, enkephalinase inhibitors could be of potential therapeutic value. We also have been interested in the question as to whether enkephalinase is identical to ACE and have used inhibitors and other studies to address the issue of identity between these two enzymes. We present here evidence that would suggest that the two enzymes are separate.

\section{METHOD}

\section{Materials}

(D-Ala ${ }^{2},-$ Leu $\left.^{5}\right)$ Enkephalinamide, (Leu $\left.{ }^{5}\right)$ enkephalinamide and (D-Ala ${ }^{2},-\mathrm{Leu}^{5}$ ) enkephalin were obtained from Biosearch. Angiotensin converting enzyme inhibitor was obtained from Beckman. Parachloromercuriphenyl sulfonic acid was obtained from Sigma. All other peptides and amino acids were from ICN. 
Enzyme Assays

The membrane preparation has been described in detail [25]. Briefly, bovine or rat caudate is homogenized in 100 volumes of 0.1 M MES ph 6.5. After centrifugation at 30,000 $\mathrm{G}$ for $20 \mathrm{~min}$ the pellet is resuspended in MES, centrifuged again, resuspended, and allowed to stand at room temperature for one hour. The preparation is then centrifuged and the pellet is resuspended in 100 volumes of $\mathrm{MES} 0.1 \mathrm{M} \mathrm{pH}$ 6.5 .

Fifty microliters of this preparation are incubated at $25^{\circ} \mathrm{C}$ for 2-10 min in the presence of $100 \mathrm{nM}{ }^{3} \mathrm{H}$-Leu-enkephalin (New England Nuclear) $25 \mathrm{Ci} / \mathrm{mmole}$ and, where applicable, $10 \mu \mathrm{l}$ of buffer or the inhibitor to be tested. Controls in which the membrane preparation has been boiled for one minute are run with each experiment. The reaction is terminated by spotting $10 \mu \mathrm{l}$ of the reaction mixture onto a thin-layer chromatography (TLC) plate of silica gel $(0.5 \mathrm{~mm}$ thick). This procedure has previously been determined to give the same results as termination of reaction by boiling. Chromatography is carried out in the system n-butanol:ethyl acetate:acetic acid:water (1:2:1:1). Markers of Leu-enkephalin, tyrosine (T), and TGG are run with all samples and the relevant areas are scraped into scintillation vials and counted. $\mathbf{R f}$ values in this TLC system are TGG 0.25 , T 0.38 , and LE 0.59 .

\section{RESULTS}

\section{Inhibitors and Characterization}

Table 1 summarizes the effects of various classes of inhibitors on both the TGG- and T-generation. In both cases enzymes appear to contain metal cofactors as evidenced by the strong inhibition produced by 1,10-phenanthroline and partial inhibition by EDTA. The minimal effect of EGTA indicates that both enzymes lack calcium dependence. Dialysis against 2000 volumes of buffer does not appreciably affect enzymatic activity, suggesting that metal cofactors are very strongly bound. Preliminary evidence from metal replacement studies suggests $\mathrm{Co}^{++}$is the metal cofactor for enkephalinase. In these studies enzyme activity was tested in the presence of either $1 \mathrm{mM} \mathrm{1,10-phenanthroline,} \mathrm{or}$ phenanthroline plus various metals at a concentration of 4 $\mathrm{mM} . \mathrm{Co}^{++}$was the only metal with ability to restore activity to control levels.

The sulfhydryl modifying agent, parachloromercuriphenyl sulfonic acid (PCMP) was found to be a selective inhibitor for aminopeptidase activity, whereas the sulfhydryl reducing agent glutathione was slightly more potent as an inhibitor of enkephalinase. Sulfhydryl groups, then, are important for the activity of both enzyme types. In the case of enkephalinase this appears to be via reduction of sulfhydryl bridges whereas for aminopeptidase activity inhibition occurs via reaction with $-\mathrm{SH}$ groups.

Degradation resistant analogues of Leu-enkephalin showed various inhibitory potencies. The two analogues altered at only one terminal elicited strong inhibition of both enzymes with the C-terminal modification having a greater effect on tyrosine generation and the $\mathrm{N}$-terminal modification having a greater effect on TGG. D-Ala ${ }^{2}-$ Leu-enkephalinamide, with modification of both terminals, was far less potent, suggesting that at least one terminal must be unaltered to permit binding at active sites. This is in agreement with Grynbaum et al. [11] who have demonstrated a prolonged half-life for the doubly substituted analogue of Met-enkephalin.

TABLE 1

INHIBITORS

\begin{tabular}{lc}
\hline $\begin{array}{l}\text { Inhibitor at } 1 \mathrm{mM} \\
\text { (no. of trials) }\end{array}$ & Percent control $\pm \underset{\mathrm{T}}{\mathrm{SEM}}$ \\
\hline
\end{tabular}

EGTA (4)

EDTA (5)

1,10 phenanthroline (9)

Parachloromercuriphenyl

sulfonic acid (10)

Glutathione (4)

D-ala²-leu-enkephalinamide (6)

D-ala-2leu-enkephalin (6)

Leu-enkephalinamide (3)

Tyr-Gly (5)

Tyr-Gly-Gly (5)

Tyr-Gly-Gly-Phe (4)

Gly-Gly (4)

Gly-Gly-Phe (8), $10 \mathrm{~min}$ preinc.

Gly-Gly-Phe (4), 2 min preinc.

Gly-Phe (4)

Gly-Gly-DL-Phe (9)

Gly-DL-Phe (5)

L-Phe (4)

D-Phe (8)

Tyr-Tyr, Leu-Leu, Leu-Gly (6)

Puromycin (4)

Bacitracin (5)
Phe-Leu (5)

$\begin{array}{rr}84.9 \pm 8.4 & 100.5 \pm 13.4 \\ 28.4 \pm 5.9 & 37.9 \pm 8.8 \\ 5.2 \pm 1.3 & 26.6 \pm 6.6 \\ & \\ 110.2 \pm 7.8 & 28.2 \pm 6.4 \\ 50.1 \pm 3.2 & 71.1 \pm 5.2 \\ 49.2 \pm 4.8 & 38.9 \pm 4.4 \\ 16.0 \pm 3.3 & 28.0 \pm 5.6 \\ 21.9 \pm 4.3 & 6.2 \pm 1.6 \\ 15.2 \pm 0.6 & 92.1 \pm 7.6 \\ 33.1 \pm 1.4 & 94.5 \pm 7.5 \\ 24.8 \pm 1.0 & 25.5 \pm 1.7 \\ 26.0 \pm 2.1 & 47.3 \pm 2.2 \\ 107.0 \pm 8.2 & 118.5 \pm 8.0 \\ 88.2 \pm 2.3 & 75.4 \pm 5.3 \\ 70.4 \pm 1.5 & 62.4 \pm 2.3 \\ 40.8 \pm 4.4 & 85.6 \pm 3.5 \\ 29.8 \pm 3.2 & 85.7 \pm 6.4 \\ 39.0 \pm 1.9 & 112.3 \pm 12.1 \\ 108.2 \pm 9.1 & 96.4 \pm 2.5 \\ 92.0 \pm 2.5 & 97.2 \pm 6.3 \\ 10.8 \pm 1.9 & 25.1 \pm 4.5 \\ 107.0 \pm 7.7 & 21.8 \pm 1.9 \\ 12.1 \pm 1.5 & 14.3 \pm 3.2\end{array}$

Inhibition of enkephalinase and aminopeptidase from rat striatum. Assays were performed as described in METHOD. All inhibitors were pre-incubated with the enzyme preparation for 10 min unless otherwise indicated. Control values were $0.91 \pm 0.12$ and $1.48 \pm 0.30 \mathrm{pmoles} / \mathrm{mg}$ tissue/hr for TGG and T generation respectively.

Of the various enkephalin fragments tested, Tyr-Gly (TG), Tyr-Gly-Gly (TGG), and Gly-Phe (GP) are selective for enkephalinase. In the case of TG and TGG, the inhibition may be via end product feedback, whereas GP may be acting through a competitive mechanism. It is of interest to note Gly-Gly-D,L-Phe (GGd/P) and Gly-D,L-Phe (GDLP) are also highly selective for enkephalinase. It was puzzling that Gly-Gly-Phe (GGP) was found to be a poor inhibitor. However, Gly-Gly-Phe's increased potency when the preincubation time was reduced from 10 to 2 min suggests that low potency is due to metabolism during preincubation. Marks et al. [18] have shown that in brain homogenates enkephalin is ultimately degraded to Gly-Gly which is relatively stable to peptidases. In our preparation, this dipeptide has relatively little inhibitory activity on either of the enzymes.

In light of the report by Ehrenpreis [5] that systemically administered D-phenylalanine has analgesic properties, it was of interest to test whether decreased enkephalin breakdown could be the mechanism of this analgesia. In our in vitro system neither D-phenylalanine nor its L-isomer was able to inhibit either enzyme. 
Henderson et al. [13] have reported that the combination of dipeptides Tyr-Tyr, Leu-Leu, Leu-Gly, will protect methionine enkephalin from breakdown in their striatal slice preparations. This combination in our system inhibits both enzymes, with a greater potency for enkephalinase.

Vogel and Altstein [28] have reported that puromycin 10 $\mu \mathrm{M}$ is able to inhibit enkephalin degradation in whole brain homogenates by $97 \%$ via inhibition of tyrosine generation. Our results confirm this finding but demonstrate no inhibition of enkephalinase.

Bacitracin is commonly used as a protective agent for enkephalins in binding assays. We found this antibiotic inhibits both TGG and T generation.

\section{Comparison with Angiotensin Converting Enzyme}

There are a number of similarities between angiotensin converting enzyme and enkephalinase. Both are membrane-bound enzymes, present in brain, and capable of cleaving enkephalin at the Gly-Phe bond. Both are metalloenzymes which are strongly inhibited by 1,10-phenanthroline. ACE in brain exhibits its highest activity in striatum as does enkephalinase. Hence there was reason to investigate the possibility that these may be identical enzymes. Our inhibitor studies had suggested a further similarity in that glutathione, known to inhibit ACE [7], also produced some inhibition of enkephalinase. However some differences between the two enzymes had also become apparent. Regional distribution in areas such as cerebellum, hypothalamus, and brainstem are apparently different for the two enzymes $[3,16,17,21,24,25,30]$ and EDTA $1 \mathrm{mM}$ produces complete inhibition of ACE but only $70 \%$ inhibition of enkephalinase.

We tested enkephalinase for two well-documented properties of ACE, namely its chloride dependence and its powerful inhibition by a nonapeptide derived from snake venom. Table 2 illustrates the effect of this inhibitor, pGlu-Trp-ProArg-Pro-GIn-Ile-Pro-ProOh, on enkephalinase. At a concentration of $200 \mu \mathrm{m}$ there is a $47 \%$ inhibition which is in marked
TABLE 2

\begin{tabular}{ccc}
\hline \multirow{2}{*}{ ACE inhibitor $\mu \mathrm{M}$} & \multicolumn{2}{c}{ Percent control/SEM } \\
& TGG & $\mathrm{T}$ \\
\hline $0.1(5)$ & $97.7 \pm 3.4$ & $85.6 \pm 4.9$ \\
$1.0(5)$ & $90.2 \pm 2.6$ & $91.3 \pm 4.3$ \\
$10.0(5)$ & $90.9 \pm 3.7$ & $85.0 \pm 6.1$ \\
$100.0(5)$ & $58.6 \pm 5.0$ & $91.1 \pm 6.0$ \\
$200.0(3)$ & $51.1 \pm 7.0$ & $82.3 \pm 3.0$ \\
\hline
\end{tabular}

Inhibition curve for the ACE inhibitor p-Glu-Trp-Pro-Arg-ProGln-Ile-Pro ProOh (Beckman). Enzyme activity was assayed as described in METHOD. Numbers in parentheses represent the number of estimations. Control values were TGG $0.85 \pm 0.15$ and $T$ $1.78 \pm 0.47 \mathrm{pmoles} / \mathrm{mg}$ tissue $/ \mathrm{hr}$. Tissue source was rat striatum.

contrast to ACE from rat brain for which this nonapeptide has an $\mathrm{IC}_{50}$ of $0.1 \mu \mathrm{M}$ or less [30].

We tested the issue of chloride dependence in two ways. First we studied the activity of enkephalinase in different buffer systems, with and without addition of chloride. We then dialyzed the enzyme and again looked at activity in the presence and absence of chloride. Data presented in Table 3 demonstrate that, of the buffers tested, enkephalinase was active only in tris- $\mathrm{HCl}$ and MES. No activity could be shown in sodium or potassium phosphate or in tris-maleate buffers. Addition of chloride had no effect in any buffer system. Extensive dialysis of the enzyme did not significantly alter activity and addition of chloride to the dialyzed enzyme had no effect. There are two points to note here: ACE of rat brain is reported to be active in both sodium and potassium phosphate buffers $[21,30]$ whereas enkephalinase is not. Moreover, rat brain ACE becomes inactive upon dialysis against chloride-free buffer, activity being restored with the addition of chloride, while enkephalinase is unaffected by chloride.

TABLE 3

BUFFER AND CHLORIDE DEPENDENCE

\begin{tabular}{|c|c|c|c|}
\hline Condition & $\begin{array}{c}\text { pmoles } / \mathrm{mg} \text { tissue } / \mathrm{hr} \\
\pm \text { SEM }\end{array}$ & Condition & pmoles/mg tissue $/ \mathrm{hr}$ \\
\hline MES (11) & $0.91 \pm 0.12$ & $\begin{array}{l}\text { Sodium phosphate } \\
+ \text { chloride }\end{array}$ & $\begin{array}{l}\text { No activity } \\
\text { No activity }\end{array}$ \\
\hline MES + chloride (5) & $0.59 \pm 0.11$ & Potassium phosphate & No activity \\
\hline Tris $\mathrm{HCl}(6)$ & $0.85 \pm 0.15$ & + Chloride & No activity \\
\hline $\begin{array}{l}\text { Dialysed prepa- } \\
\text { ration (15) }\end{array}$ & $0.77 \pm 0.03$ & $\begin{array}{l}\text { Tris maleate } \\
+ \text { chloride }\end{array}$ & $\begin{array}{l}\text { No activity } \\
\text { No activity }\end{array}$ \\
\hline $\begin{array}{l}\text { Dialysed }+ \\
\quad \text { chloride }(2)\end{array}$ & $0.81 \pm 0.004$ & & \\
\hline
\end{tabular}

Enkephalinase activity in different buffer systems in the presence and absence of $100 \mathrm{mM}$ sodium chloride. All buffers were $0.1 \mathrm{M} \mathrm{pH}$ 6.5. Dialysis was performed for $18 \mathrm{hr}$ against 5000 volumes of MES buffer. Enzyme activity was measured as described in METHOD. Numbers in parentheses indicate the number of trials. 


\section{DISCUSSION}

In this paper we have addressed several issues pertinent to enkephalin degradation in brain. Our inhibitor studies have allowed preliminary characterization of enkephalinase and tyrosine-producing aminopeptidases in brain. Enkephalinase appears to be membrane-bound while the aminopeptidases are more soluble. Both types of enzyme are metalloenzymes which are inhibited by modification of sulfhydryl groups. T-generation is selectively inhibited by PCMS and puromycin while enkephalinase is inhibited by the enkephalin fragments TG, TGG, GP, GDLP and GGDLP. These selective inhibitors could prove to be useful in studies designed to test the physiological significance of each type of enzymatic cleavage.

Both enzymes are strongly inhibited by Leu-enkephalin analogues. These analogues have been shown to produce powerful opiate-like effects when administered in vivo, effects which have been attributed to their activation of opiate receptors. Since they are powerful inhibitors of enkephalin breakdown, it is also possible that they could increase endogenous enkephalin levels within the synapse and this may contribute to their in vivo activities. On the other hand, D-phenylalanine, which has been reported to produce analgesia apparently does not act by inhibiting enkephalin breakdown.

With regard to the question of identity between $\mathrm{ACE}$ and enkephalinase, we have produced cogent evidence that these are different enzymes. Two characteristic properties of ACE, inhibition by a snake venom nonapeptide and chloride dependence, were tested in relation to enkephalinase. In both cases enkephalinase behaved very differently from $A C E$. In addition, ACE is active in sodium and potassium phosphate buffers whereas enkephalinase is not. Thus despite some similarities between ACE and enkephalinase it appears that these are different enzymes in brain. There is some controversy in the literature regarding this finding. Benuck and Marks [3] feel that the two enzymes are identical. However, recent studies by Swerts et al. [27], Gorenstein and Synder [9], and Arregui [1] support our contention. Each of these investigators have demonstrated differentiation between enkephalinase and converting enzyme.

The distribution of enkephalinase, then, parallels that of enkephalin and the opiate receptor $[17,25]$. We have shown here that enkephalinase is sensitive to inhibition by enkephalin fragments which could represent a feedback inhibition. Enkephalinase can be distinguished by various means from amino-peptidases and converting enzyme in the systems we have studied. These data are consistent with enkephalinase being the enzyme in brain which is specific for the endogenous enkephalinergic system.

\section{ACKNOWLEDGMENTS}

Supported by NIMH Program-Project grant MH23861 and NIDA grant DA01207.

\section{REFERENCES}

1. Arregui, A., C-M. Lee, P. C. Emerson and L. L. Iversen. Separation of human brain angiotensin-converting enzyme from enkephalin-degrading activity. Eur. J. Pharmac. 59: 141-144, 1979.

2. Benuck, $M$. and N. Marks. Inhibition of brain angiotensin-I converting enzyme by Bothrops Jararaca nonapeptide (SQ 20881) and a prolyl analog (SQ 14225). J. Neurochem. 30: 1653-1655, 1978.

3. Benuck, M. and N. Marks. Co-identity of brain angiotensin converting enzyme with a membrane bound dipeptidyl carboxypeptidase inactivating met-enkephalin. Biochem. Biophys. Res. Comm. 88: 215-221, 1979.

4. Dupont, A., L. Cusan, M. Garon, G. Alvarado-Urbina and F. Labrie. Extremely rapid degradation of "H-methionine-enkephalin by various rat tissues in vivo and in vitro. Life Sci. 21: 907-914, 1977.

5. Ehrenpreis, S., J. E. Comaty and S. B. Myles. Naloxone reversible analgesia produced by d-phenylalanine in mice. Soc. Neurosci. Abstr. 1457, Nov. 1978.

6. Elde, R., T. Hokfelt, O. Johansson and L. Terenius. Immunohistochemical studies using antibodies to leucineenkephalin: initial observations on the nervous system of the rat. Neuroscience 1: 349-351, 1976.

7. Erdos, E. G. The angiotensin I converting enzyme. Fedn. Proc. 36: 1760-1765, 1977.

8. Erdos, E. G., A. R. Johnson and N. T. Boyden. Inactivation of enkephalins: effect of purified peptidyl dipeptidase and cultured human endothelial cells. In: The Endorphins. Advances in Biochemistry and Psychopharmacology, Vol. 18, edited by E. Costa and M. Trabucchi. New York: Raven Press, 1978, pp. $45-49$.

9. Gorenstein, C. and S. Snyder. Characterization of enkephalinase. In: Endogenous and Exogenous Opiate Agonists and Antagonists, edited by E. L. Way. New York: Pergamon Press, in press. 10. Graves, F. B., P. Y. Law, C. A. Hunt and H. H. Loh. The
metabolic disposition of radiolabeled enkephalins in vitro and in situ. J. Pharm. exp. Ther. 206: 492-506, 1978.
11. Grynbaum, A., A. J. Kastin, D. Coy and N. Marks. Breakdown of enkephalin and endorphin analogs by brain extracts. Brain Res. Bull. 2: 479-484, 1977.

12. Hambrook, J. M., B. A. Morgan, M. J. Rance and C. F. Smith. Mode of deactivation of enkephalins by rat and human plasma and rat brain homogenates. Nature 262: 782-783, 1976.

13. Henderson, G., J. Hughes and H. W. Kosterlitz. In vitro release of leu- and met-enkephalin from the corpus striatum. Nature 271: 677-679, 1978.

14. Hughes, J. Isolation of an endogenous compound from the brain with pharmacological properties similar to morphine. Brain Res. 88: 295-308, 1975.

15. Iversen, L. L., S. D. Iversen, F. E. Bloom, T. Vargo and R. Guillemin. Release of enkephalin from rat globus pallidus in vitro. Nature 271: 679-681, 1978.

16. Malfroy, B., J. P. Swerts, A. Guyon, B. P. Rogues and J. C. Schwartz. High affinity enkephalin degrading peptidase in brain is increased after morphine. Nature 276: 523-526, 1978.

17. Malfroy, B., J. P. Swerts, C. Llorens and J. C. Schwartz. Regional distribution of a high-affinity enkephalin degrading peptidase (enkephalinase) and effects of lesions suggest localization in the vicinity of opiate receptors in brain. Neurosci. Lett. 11: 329-334, 1979.

18. Marks, N., A. Grynbaum and A. Neidle. On the degradation of enkephalins and endorphins by rat and mouse brain extracts. Biochem. Biophys. Res. Comm. 74: 1552-1559, 1977.

19. Meek, J. L. and T. P. Bohan. Use of high pressure liquid chromatography (HPLC) to study enkephalins. In: The Endorphins. Advances in Biochemistry and Psychopharmacol$o g y$, Vol.18, edited by E. Costa and M. Trabucchi. New York: Raven Press, 1978, pp. 141-146.

20. Meek, J. L., H-Y. T. Yang and E. Costa. Enkephalin catabolism in vitro and in vivo. Neuropharmacology 16: 151$154,1977$.

21. Poth, M. M., R. G. Heath and M. Ward. Angiotensin converting enzyme in human brain. $J$. Neurochem. 25: 83-85, 1975. 
22. Simantov, R., M. J. Kuhar, G. R. Uhl and S. Snyder. Opioid peptide enkephalin: immunohistochemical mapping in rat central nervous system. Proc. natn. Acad. Sci. U.S.A. 74: 2167$2171,1977$.

23. Snyder, S. H. Clinical relevance of opiate receptor and opioid peptide research. Nature 279: 13-14, 1979.

24. Sullivan, S., H. Akil and J. D. Barchas. Enkephalin catabolism in the presence of an opiate receptor preparation from rat brain. Soc. Neurosci. Abstr. 1315, Nov., 1978.

25. Sullivan, S., H. Akil and J. D. Barchas. In vitro degradation of enkephalin: evidence for cleavage at the Gly-Phe bond. Communs. Psychopharm. 2: 525-531, 1978.

26. Swerts, J. P., R. Perdrisof, B. Malfroy and J. C. Schwartz. Is "enkephalinase"" identical with "angiotensin-converting enzymes?' Eur. J. Pharmac. 53: 209-210, 1979.
27. Swerts, J. P., R. Perdrisof, G. Patey, S. De La Baume and J. C. Schwartz. "Enkephalinase" is distinct from brain "angiotensin-converting enzyme." Eur. J. Pharmac. 57: 279-281, 1979.

28. Vogel, Z. and M. Altstein. The effect of puromycin on the biological activity of leu-enkephalin. FEBS Lett. 98: 44-48, 1979.

29. Watson, S. J., H. Akil, S. Sullivan and J. D. Barchas. Immunocytochemical localization of methionine enkephalin: preliminary observations. Life Sci. 21: 733-738, 1977.

30. Yang, H-Y. T. and N. H. Neff. Distribution and properties of angiotensin converting enzyme of rat brain. $J$. Neurochem. 19: 2443-2450, 1972. 